\title{
On Heideggerian Sense of Interpretation (II) ---- The As-Structure as Disclosure
}

\author{
Qu Ping \\ Department of Foreign Languages, Henan Institute of Engineering, Zhengzhou 451191, China \\ pingyuanmei686@163.com
}

\begin{abstract}
Heidegger's sense of interpretation has a closely inherent relationship (kinship) with his sense of understanding, the former is founded by the latter, and the latter is presupposed by the former. Interpretation is a derivative mode of understanding and gets explicit understanding. The former is ontical and empirical, while the latter is ontological and transcendental. In order to make explicit the question of the meaning of interpretation and its kinship with understanding, let us start from an introduction.
\end{abstract}

Index Terms - Heidegger's sense of interpretation, understanding, interpretation

\section{The As-structure of Interpretation}

As has been mentioned, the as-structure is inherently implied in the ontological difference (being/beings) with which Heidegger establishes the whole structure of his work Being and Time. He claims that there will be no access to any entities without apriori understanding of their being. That is the reason why entities to which we comport ourselves appear as if they have been always already understood in one way or another beforehand. As Heidegger tells us, "We always conduct our activities in an understanding of Being. ... But even if we ask, "What is "Being'?", we keep within an understanding of the 'is', though we are unable to fix conceptually what that 'is' signifies. ... But this vague average understanding of Being is still a Fact" (BT, 25). It is "this vague average understanding of Being" that first and for the most part puts us into a state of "being directed" to seek entities which have already been understood within the limit prescribed by our understanding of being. "To gain the guidance of being" and "being-guided by the being" cannot be separated into two independent events, as if "the guiding-activity" is one thing while "the being-guided" is another. In fact, to obtain an understanding of being and being guided by the understanding of being to look for beings take place at the same time, they are simultaneous, like the two sides of a coin. Being is always the being of entities, and entities are always the entities of being. The former arises out of the latter in a way of pre-conceptual being-worldly generalization and returns to the latter in a way of being-guidance. These two ways only belong to the human being; which Heidegger calls the ontological difference: the ontological and ontical distinction, or the dichotomy between being and beings. Understanding and interpretation with such dichotomy have the characters of being and beings.

It is obvious that understanding and interpretation are two poles: one is high up, or low down, at the ontological level; the other is low down, or high up, at the ontical one. They are inherently unified in a human being: "Dasein is ontically distinctive in that it is ontological" (BT, 32). How is it possible? How are they unified? What is it that bridges the two poles? The answers have been hit on in the foregoing passages, but they are too sketchy to meet our demands. Next we will try to give a detailed description in the light of Heideggerian sense of interpretation. We tentatively put forward two points: one is "understanding is global, interpretation is local"; the other is "interpretation is the explicit understanding".

\section{Understanding Is Global, Interpretation Is Local}

Since, as has been discussed, understanding is a holistic structure, it naturally follows that "understanding is global" because a "holistic structure" as an encompassing network of relations is nothing else than the human being's globe, not in a geological, but in an existential-ontological, sense. That the human being's understanding is global is so defined as soon as the human being's understanding of being is constituted. Heidegger believes that every kind of understanding is already in being, that is, is already a being, and therefore is already an understanding of being. In virtue of this, it is already a phenomenological world or the worldhood of the world, in the sense of equiprimordiality.

Another fact that the human being's primary understanding of being is a global world lies in the human being's facticity of being-in-the-world. As we have mentioned, the being-in-the-world is a compound expression which refers to the most basic, the most primordial state of a human being. This "world" cannot be understood as a total sum of entities pieced together, this "world" must be understood as a system of relations, a network of significance, in short, as a phenomenological world which is characterized by various "for-which" and "towards-which". Existing in such a phenomenological world, a human whose understanding of being has no other choice but be adapted to this world; it cannot but belong to a system of relations as its primary understanding of being of this world. This is an implied meaning of Heidegger's another term "having-to-be" (BT, 173) which he uses to disclose a human being's being-in-the-world.

One may ask: Is this "world" static or dynamic, in which a human being lives? Heidegger would probably answer, "It is dynamic". For a human being by his definition, or by his essential character is his existence of "being-there", which signifies a potentiality-for-being, a having-to-be; but even the "being" of this "world" must depend on the human being: there is a world if and only if there exists the human being. 
Only the human being has "world", other species are worldless. The human being's understanding must be global unless he does not have the character which a human being has in general. As mentioned just now, a human being is doomed to be in his being-in-the-world unless he is not being any longer. This doomedness Heidegger calls in his terminology "being-thrownness". A human being's "having-to-be" is disclosed by his "being-thrownness". We as human beings cannot but be thrown into the world which is always already constituted by various significations: "As being, Dasein is something that has been thrown; it has been brought into its 'there', but not of its accord. As being, it has taken the definite form of a potentiality-for-Being which has heard itself and has devoted itself to itself, but not as itself. As existent, it (Dasein) never comes back behind its thrownness in such a way that it might first release this 'that-it-is-and-has-to-be' from its Being-its-self and lead it into the "There" (BT, 329-330). "Being-thrownness" is an ontological conception which signifies its equiprimordiality with understanding of being, state-of-mind, as well as being-in-the-world. We are thereby thrown into "a whole of significance" (BT, 192). But how is our understanding of being set in motion if we are absolutely passive in the state of being-thrownness at least at the very beginning of our primordial understanding of being? In order to solve this dilemma, Heidegger discovers that just in our "thrownness" there is buried "throwing", or "to throw", i.e. "projecting". Obviously, this finding is set up on a shifted point of view: from the angle of a human being, he is thrown; but from the world of significance, a human being throws or projects. Still, projecting or throwing means that there must be something to be thrown or projected at the same time. What, then, is this "something"? Heidegger tells us that it is the "understanding" or "understanding of being". How is it possible? It is the understanding, too, because "Dasein is an entity which, in its very Being, comports itself understandingly towards that Being" (BT, 78; italics added), and "To be sure, its (Dasein's) ownmost Being is such that it has an understanding of that Being, and already maintains itself in each case as if its Being has been interpreted in some manner" (BT, 36; italics added). This unique phenomenon (because only man possesses) is designated as "thrown projection": "And as thrown, Dasein is thrown into the kind of Being which we call 'projecting'" (BT, 185).

Thus a connation, or even an equation between "thrownness" and "projection" is set up. As far as we know, Heidegger, by playing on words of "throwing" and "thrownness", aims at disclosing the character of "two sides of one coin" of a human being's understanding of being. Thrownness means being bound up by the world of significance into which a human being is helplessly thrown while "projecting" or "throwing" requires something set free, or released from that world. All these activities are undertaken in a human being, and must presuppose that a human being has been put into a state of being bound up in the phenomenological world. At the same time, this world must allow a human being some leeway for projecting of that being.
This calls into our attention a human being's possibilities for being or existence.

As has been disclosed, a human being's most basic state is his being-in-the-world which "has already got itself into definite possibilities" (BT, 183). Upon this reading, if the being-in-the-world is not at all equivalent to possibilities of the human being's being, where can we go? Since the being-in-the-world is a world of symbolic structure or a totality of various assigning processes, have not the "possibilities" thereby become obvious? Symbolizing, or assigning, on Heidegger's view, means "towards-which" and "for-which". Suppose that the human being in the world is always bound up tightly everywhere, where can we have the ground upon which the interconnection between the two poles of being and beings is founded? Therefore the world of symbolic structure must provide "possibilities" upon that which it has already had. Yet in the light of Heidegger's existential analysis of the human being, this world is nothing else than the human being himself: "To say that in existing, Dasein is its 'there', is equivalent to saying that the world is "there" (BT, 182). That is, to say that the world or the worldhood of the world has possibilities is no more than to say the human being has possibilities.

We have said that the human being's thrownness in itself has already implied the function of projection as soon as thrownness comes into being in the human being. Thrownness is thrown into a world of significance and hence it is in essence a world of significance which turns out to be the basis for projection. Here, to say "the human being's thrownness" has the same value as that to say "the human being has his being-in-the-world". For this reason, the human being's thrownness is the ground upon which an understanding sets in motion. Thrownness is the basic mode of the human being's disclosedness: “To Dasein's state of Being belongs thrownness; indeed it is constitutive for Dasein's disclosedness" (BT, 264). It is in the thrownness that an understanding begins. Thrownness is global because the human being has no means to escape from his being thrownness. But along thrownness, being-thrown-possibilities for being are thrown, too. These possibilities are nothing but the definite characters of understanding: "Understanding is the Being of such potentiality-for-Being ... Understanding is the existential Being of Dasein's own potentiality-for-being" (BT, 183/184). "Why does the understanding ... always press forward into possibilities? It is because that the understanding has in itself the existential structure which we call 'projection' " (BT, 184-85). Here, Heidegger definitely connects or gets through understanding with projection and thrownness (projectedness). Now, Heidegger can say, "The character of understanding as projection ..." (BT, 185).

In sum, thrownness is the primordial state of the human being's being-there, it signifies a world of significance (the phenomenological world), and accordingly it carries with itself the definite possibilities from which an understanding as a mode of projection is able to set in motion. "Only from out of definite possibilities, from out of 'the leeway of factical potentiality for being', can understanding as a form of 
projection take place" (HW, 48). But, this is not the whole story of understanding. Understanding as a form of projection, as the most basic mode of the human being's disclosedness, has no reason at all to stop here. We may say that that which constitutes an understanding is not probably and usually got explicit in its empirical interpretation, but we should not say that there is no understanding in the interpretation at all. Understanding, as described, is worldly global; interpretation, as "the development of understanding" (BT, 188), can only develop itself within the global understanding, and accordingly result in localization or thematization of its understanding, and nothing more.

To claim that "the interpretation is local, thematic" means that it signifies that part of the global understanding of world wins the chance of getting explicit, thematic. The relationship between the human being's understanding and interpretation is constituted and prescribed by the economic law of cost-effectiveness. Whether or not an understanding is needed to be made explicit, what part of an understanding is needed to be made so and so, and how the needed part of an understanding gets explicitly, thematically foregrounded, largely and reasonably depend on the purpose of the "in-order-to-be" and the "for-the-sake-of-which". Therefore, a global, unthematic understanding of world does not necessarily make itself thematically explicit in an entirety. In fact, it is thoroughly impossible to make a global, unthematic understanding of world thematically explicit in terms of its totality whose character is made up by various significant relations which always exist in various involvements; in addition to the fact that being-global existentially implies that it is always constitutive, contingent, relational, and indeterminative. An interpretation as a thematically local expression of the global, inexplicit understanding thematically foregrounds or lays out part of the primary global understanding on the one hand; while on the other hand it conceals or covers up most part of the primary global understanding by pushing it into a being-backgroundedness. This kind of phenomenon about the primary understanding and its derivative mode of explicit interpretation is captured by Heidegger's dialectical relationship between unconcealment and concealment in the very act of understanding of being. This phenomenon of thematically coming out of the primary, amorphous, global understanding into a derivative, thematic, local interpretation is the definite process of making the understanding explicit, which is the one theme (among others) that takes up the large part of Heidegger's investigation of "the question of the meaning of being" (BT, 19) in his phenomenological hermeneutics. By now, the equivalence appears explicit between the two statements: "understanding is global, interpretation is local" and "understanding is the entire scope of ability, while interpretation is the concrete reification of this ability". In other words, an interpretation is never free-floating, but is always rooted in the primary global understanding. Finally, let us use a metaphor to explicate this kind of constitutive/constituted relationship.

\section{Conclusion}

It is a metaphor with which we are familiar: that which shows itself is what is exposed above water and that which is kept in darkness is what is covered under water. The exposed is just a small part of the iceberg whose larger part remains submerged; however, it is the small part that tells the rest of the iceberg, and lets us give it a whole picture. So too, although our primary global understanding of being largely keeps itself covered up from our sight and beyond our immediately thematic local interpretative apprehension, that it keeps secret or inconspicuous may well be the very reason that we usually interpret things empirically and explicitly in a certain particular manner. The primary global understanding of being with the ultimate purposiveness of "towards-which" projects itself in a way in which its constitutive ability is reified in the form of thematic local interpretation. Thinking over the problem of the meaning of the thematic local interpretation in terms of its reification of the primary global understanding of being, we have already been delivered over to this question "an interpretation is the explicit understanding".

\section{Acknowledgment}

The paper is the initial accomplishment of the program assigned by Henan Science and Technology Department in 2013: A Study on the Translators in Phenomenological Perspective in Henan. No: 132400410300; also sponsored by Social Science Program issued by Educational Bureau of Henan.

\section{References}

[1] Heidegger, Martin. Being and Time. John Macquarrie \& Edward Robinson (trans.) China Social Sciences Publishing House Chengchengh Books Ltd., 1999.

[2] Culler, Jonathan. On Deconstruction: Theory and Criticism after Structuralism. Beijing: Foreign Language Teaching and Research Press, 2004.

[3] Gadamer, Gorg. Truth and Method. Garpett Barden \& John Cimming (trans.) Beingjing: China Social Sciences Publishing House Chengch Books Ltd., 1999. 